DOI 10.38129/Ann.Yur.Ist.2019.3.1.2.116

УДК 342.156

\title{
РОЗВИТОК ІДЕЇ НАРОДНОГО СУВЕРЕНІТЕТУ ЗА ДОБИ СЕРЕДНЬОВІЧЧЯ: ДЕРЖАВНИЙ ТА ЦЕРКОВНИЙ ВИМІРИ
}

\author{
ВЛАДИСЛАВ САСІН (Київ, Україна)*
}

Народний суверенітет - це один із базових принципів демократії, що $\epsilon$ предметом жвавих політико-юридичних дискусій та обговорень. Як і будь-яка теоретико-методологічна категорія юриспруденції, народний суверенітет має свою термінологічну історію й нероздільно пов'язаний із боротьбою за права і свободи людини, формуванням уявлень про громадянство й підданство, становленням демократичних режимів в європейському та загальносвітовому вимірі, багатьма іншими процесами, що відображають сутнісні характеристики демократичного дискурсу.

Європейське Середньовіччя зіграло чималу роль для розвитку категорії народного суверенітету, попри загальновизнану оцінку Раннього та Високого Середньовіччя як періодів, в яких про демократію та прояви народовладдя годі й говорити. Формування ідей народного суверенітету в епоху Середньовіччя, на думку відомого дослідника, випускника Імператорського університету імені Святого Володимира М. Палієнка, викликано багатьма чинниками: рецепцією римського права та правової спадщини Давнього Риму, особливостями становлення державності в германців, феодальним договірним характером відносин між сюзереном і васалом, князями і станами (верствами), уявленнями про початковий природний стан, де не існувало дуалістичного інституту пануванняпідкорення, аналізом спадщини Аристотеля та рефлексією античної демократії ${ }^{196}$.

Поговоримо більш детально про всі ці чинники.

Феодалізм став однією 3 характерних рис Раннього та Високого Середньовіччя, а вже за часів Пізнього розпочинаються процеси розладу феодальних відносин і постає етап формування національних держав у вигляді абсолютних монархій. Сутність феодалізму відображають відносини сюзерен-васал, які носили договірний характер. На своєму

196 Н. Палиенко. Суверенитет: Историческое развитие теории суверенитета и ее правовое значение. - Ярославль: Тип. Губ. правл., 1903. - 591 с. 
початку, феодалізм, в певній мірі, постав протилежністю ідеї єдиної імперії. Саме подолання феодалізму стало тим моментом, який дозволить в майбутньому (XVI ст.) говорити вже про категорію державного суверенітету. На перший погляд, здається, що феодальний лад за своєю суттю $є$ запереченням ідей народного суверенітету, адже пропонує нам лад, в якому «королі мали себе за сюзеренів - верхівку піраміди особистої залежності. Місцеві володарі привласнили собі право на особу та майно своїх підданих право чинити суд, карати, збирати податки, отримувати ренту і послуги» 197.3 цим важко не погодитися, але саме феодалізм, а точніше процеси його розладу, потягнули за собою розвиток самоврядування в місті й церкві, які фактично ознаменовували руйнування вертикальних зв'язків і натомість утвердження горизонтальних відносин у певній спільноті. 3 іншого боку, цей закономірний процес підтверджує теза відомого дослідника Середньовіччя Джона Гіттінгера про те, що «групове життя - це один із найголовніших внесків Середньовіччя. Місцеві групи й міські громади, комуни і гільдії, релігійні ордени і єпархії - усі вони мали власні способи самоврядування ${ }^{198}$ ». Енщиклопедія політичної думки Міллера також зазначає, що зі спробами кодифікувати і стандартизувати узвичаєну феодальну практику на всіх теренах усталювався корпоративний погляд на суспільство - його практичною основою стало утворення й розвиток ремісничих цехів, а теоретичною - узаконення римським правом самоврядних автономних громад ${ }^{199}$, що є фактичним підтвердженням думки Джона Гіттінгера.

Феодальні володарі намагалися підпорядкувати собі навколишні церкви і монастирі, розташовані на їхній території й призначати на місця єпископів і абатів «своїх людей» - людей, які дуже часто не дбали про свої обов'язки і служіння. У той же час, відбуваються процеси реформування в церковному житті, що призводять до докорінних змін в чернецтві, а надалі - у відносинах між місцевим феодалом і локальними монастирями. Так, у 910 році ченці монастиря в Клюні склали хартію, яка забороняла втручатися феодалу в справи монастиря і церкви, постановила їхню незалежність від будь-якої влади, окрім папської та надала їм право самостійно обрати абата зі свого кола, що перетворювало цю організацію середньовічного громадянського суспільства на юридично автономну громаду ${ }^{200}$.

197 Міллер Д. Енииклопедія політичної думки. - Київ: «Дух і літера», 2000 - С. 358.

198 Единбурзъкий погляд на історію демократії від давніх часів до майбутніх можливостей / за ред. Б. Айзехена та С. Стоквела. - Харків: Фоліо, 2017. - С. 193. 199 Міллер Д. Енциклопедія політичної думки. - Київ: «Дух і літера», 2000 - С. 358. 200 Там само. 
Тома Аквінський також захищав нові релігійні ордени і стверджував, що люди мають право об'єднуватися задля доброї справи, перетинаючи межі станів і класів.

Виходячи за межі усталеної традиції та привілеїв, Тома Аквінський захищає нові релігійні ордени за допомогою права на заснування «нових форм свободи об'єднань ${ }^{201 » . ~ Т а к и и ̆ ~ с п о с і б ~ р е л і г і и ̆ н о г о ~ ж и т т я ~ а п е л ю в а в ~ д о ~}$ первісного християнства, де життя членів громади зводилося до рівності, участі кожного вірного в житті спільноти та відсутності процесів панування-підкорення.

Утворення гільдій також постало взірцем самоуправління.

Як «професійна група», гільдія могла встановити власні стандарти допуску до професії. Гільдії не просто не підлягали контролю з боку політичної влади феодала-землевласника, а й ставали альтернативною моделлю спільного обговорення суспільно значущих питань. Вплив гільдії на процеси життєдіяльності усього суспільства (суспільство, як зазначалося pаніше, являло собою «соттипіtаs communitatem», себто фредеративну групу piзних груn) полягав у їхній ролі в управлінні містом, а в деяких випадках наприклад, у Марселі - в безпосередньому здійсненні повноцінного міського самоврядування 202.

Такого виду корпораціями можна вважати і феномен середньовічних університетів, які виникають наприкінщі XI століття і стають достойною заміною церковним школам. Кожен член університетської спільноти (наприклад, в Парижі чи Оксфорді) отримував дозвіл на викладання від церкви. Так відбулося зростання кількості світського духовенства, яке мало монополію на писемність і систематизовану освіту. До університетських спільнот долучалися i представники жебрацьких католицьких орденів (бенедиктинщі, францисканщі, домініканці); університети ставали платформою, де виховувалися покоління королівських чиновників і радників. Саме за їхнього сприяння відбулася рецепція римського світського права, ідей Цицерона про суспільство як організм, а надалі (XII cm.) постають концепції природного права, правових засад, lex regia (права управляти) та права справедливості 203 .

Рецепція римського права, яке стало сутнісною основою для просування ідей народного суверенітету, представництва, секуляризації в

201 Hittinger R. Reasons for a Civil Society. T. Fuller and J. Hittenger (eds), Washington, DC: Catholic University of America Press, 2001. - pp. 11-23.

202 Единбурзъкии погляд на історію демократії від давніх часів до майбутніх можливостей / за ред. Б. Айзехена та С. Стоквела. - Харків: Фоліо, 2017. - С. 196.

203 Міллер Д. Енциклопедія політичної думки. - Київ: «Дух і літера», 2000 - С. 358. 
Середньовіччі здійснювалася світськими правителями на противагу канонічному праву, що постало у результаті Григоріанської реформи XI ст., котра викликала за собою появу Граціанового систематичного зводу канонічного права. До складу джерел канонічного права увійдуть закони, відібрані з постанов багатьох церковних соборів, теологічних тверджень отців церкви та папських декретів, що їх видавало папство в намаганні реформувати та централізувати католицьку церкву. Водночас, германські імператори, особливо Фрідріх I (Барбаросса), заохочували усебічне рецепіювання римського права, адже воно, у сукупності 3 пізніше відкритими працями Аристотеля про етику і політику, стало засобом, за допомогою якого було докорінно змінено економічний, політичний та філософський лад Середньовіччя ${ }^{204}$. Як висновок, римське і канонічне право від кінця ХІ ст. стають антиномічною дихотомією, в якій розвивається імператорська i папська полеміка щодо розуміння співвідношення державної і церковної влади, сутності людини та соціального виміру природи загалом.

Принцип римського права - «те, що стосується усіх, має встановлюватися усіма» - відіграв важливу роль в обгрунтуванні ідеї народного суверенітету відомими англійськими правниками Джоном Солсбері та Генрі Бректоном.

У творах Солсбері, а особливо в трактаті «Policraticus» (1156-1159), відбулося відродження багатьох ідей изиеронового вчення про республіку, природний закон та справедливість; цей доробок вважається одним 3 найкращих до часів, коли європейцями були наново відкриті й рецепійовані твори Аристотеля.

Солсбері розмежовує поняття доброчесного правителя і тирана: «Між тираном і правителем є та одна чи головна відмінність, що останній кориться законові і править народом згідно з законом, вважаючи себе слугою народу. Саме завдяки закону стає добрим його намір посісти найвидатніше й найчільніше місце в керуванні справами держави ${ }^{205}$ ». I надалі підводить питання до того, чи є король підвладним тим законам, які існують у республіці. «Хай обілювачі правителів... трублять, що король непідвладний законові і що будь-які його воля й бажання, не лише в установленні законів відповідно до моделі рівності, а цілковито звільнені від усіх обмежень, мають силу закону... Я все-таки твердитиму, що королі підвладні цьому законові $206_{» .}$

204 Міллер Д. Енциклопедія політичної думки. - Київ: «Дух і літера», 2000 - С. 358.

205 Себайн Джордж Г., Торсон Томас Л. Iсторія політичної думки. - К., 1997. - С. 237. 206 Міллер Д. Енциклопедія політичної думки. - Київ: «Дух і літера», 2000 - С. 358. 
Отже, з цих слів можна зрозуміти, що для Дж. Солсбері саме закон є тим важелем, який утримує державця від того, аби він скотився до рівня тирана. I установлення цього закону, з одного боку, лежить на Божому провидінні (закон - це дар Божий і саме на духовенстві лежить обов'язок навчати йому правителів), а з іншого - на народі, адже існує природне знання морального закону (aeguitas), подібне до поглядів Цицерона, яке людина може пізнати за допомогою власної розумової діяльності.

Погляди Генрі Бректона (пом. 1268 р.) ще глибше пронизані розумінням народу як джерела влади у державі. У його творі «Про закони і звичаї Англії» зазнчається, що королівська влада має реалізовуватись, насамперед, у судочинстві, а не в законотворчості. Творення законів, у свою чергу, лежить на усьому суспільному загалі: король лише висловлює згоду 3 тими законодавчими актами, які є ухваленими народом 207.

Ідеї народного суверенітету огортали не тільки світську сферу тогочасних правників, але були наявні і серед церковних мислителів. Так, наприклад, ще під час боротьби за інвеституру (XI століття) німецький монах Манегольд Лаутенбазький зазначав, що влада світських правителів, імператора і короля, має делегований характер (vocabulum officii). Тому у випадках порушення умов цієї угоди про делегування повноважень, народ навіть наділяється правом позбавити монарха його титулу: «тирана народ може позбавити корони як негідного пастуха».

Упродовж XII століття література також досліджує питання про підвалини імператорської влади та про ії відносини з народом. Юристи Болонської школи, на основі римського права, визнали верховну владу германських імператорів абсолютною та отриманою внаслідок законної спадкоємності від римських імператорів. У літературі зазначаються i демократичні ідеї, що народ не передає саму владу імператорові, а лише передає право здійснювати цю владу, залишивши саме право на владу в себе. Влада імператора має делегований характер. Звідси випливало право народу видавати закони, які були б обов'язковими, як для імператора, так і для народу. Також противники папства, спираючись на норми римського права, виводили світську владу з початкової влади народу, щоб у такий спосіб заперечити вчення папства та їхніх каноніків про те, що земна влада встановлюється духовним чином і, відповідно, папою208.

Сама ідея про папу як представника Христа сприяла появі паралельного

207 Міллер Д. Енщиклопедія політичної думки. - Київ: «Дух і літера», 2000 - С. 42.

208 Н. Палиенко. Суверенитет: Историческое развитие теории суверенитета и ее правовое значение. - Ярославль: Тип. Губ. правл., 1903. - С. 68-69. 
уявлення про політичного лідера як представника народу. Це стало причиною того, що упродовж XIII ст. постали два дихотомічні підходи щодо розуміння держави і суверенності у ній. Перша 3 них зазначала, що джерелом усієї земної влади є Бог, а отже, монарх є помазаником Божим, він є єдиним каналом влади у державі. Натомість другий підхід мав демократичний характер і наголошував на «суверенності народу, яка розглядалася у рамках системи комунального, гільдійного чи міського самоврядування або делегування вихідної колективної влади довіреній особі, що уособлює рішення корпоративної більшості 209 ». Джерелами такого підходу, з одного боку, є звичаї давньогерманського народу, який залишав за групами індивідів правовий інститут протистояння самодержавству короля, який згодом був легітимізований через норми рецепійованого римського права; 3 іншого боку, цей підхід став наслідком розвитку тих урбаністичних регіонів, де формувалася торговельна й ремісницька буржуазія, - спершу для забезпечення просування торгівлі та пов'язаною 3 нею практик, але згодом вона розвинулася до рівня автономного самоврядування, а врешті і до колективного управління спільнотою та містом, як, наприклад, це відбувалося у Франції (Марсель) та Італії (Генуя, Венеція тощо).

В тогочасних справах церкви також спостерігалися процеси, які вказують на інститути представництва та народного суверенітету. Так, абатства, соборні збори каноніків та жебрацькі ордени, про які зазначалося вище, продовжували проводити вибори абатів, єпископів і представників відповідних об'єднань; вся власність вважалася колективною, тож єпископ чи навіть папа діють лише як розпорядники майна210.

Німецький юрист, професор Отто фон Іірке вважав, що таке громадське i духовне представництво походить також від звичаїв германських племен: вождь представляє плем'я, отже, вождь представляє громаду своїх підданих 211 . Отже, право громади перетворилося на доктрину народного суверенітету. Збори представників також могли стати суб'єктом реалізації права громади. «Персоніфікація громади, - як доцільно вказує Джон Гіттінгер, - стає для неї інструментом колективної дії212».

У XIII столітті європейцями було наново відкрито твори Аристотеля і саме поняття аристотелівського «спільного блага», разом із

${ }^{209}$ Міллер Д. Енциклопедія політичної думки. - Київ: «Дух і літера», 2000 - С. 359.

210 Там само.

211 Hattersley A. F. A Short History of Democracy. Cambridge: Cambridge University Press, 1930. - P. 96.

212 Единбурзъкий погляд на історію демократії від давніх часів до майбутніх можливостей / за ред. Б. Айзехена та С. Стоквела. - Харків: Фоліо, 2017. - С. 198. 
вищезазначеними чинниками, сприяло утвердженню римського приниипу публічного права, відповідно до якого король є слугою народу, щуо керує задля спільного блага.

Праці Аристотеля, а особливо «Політика», стали переломним моментом у формуванні політичної філософії XIII-XV століть та продемонстрували різність поглядів на феномен народного суверенітету та місця народу у здійсненні влади у державі. Одна частина філософів, яких визнавала ортодоксальна католицька церква, на чолі яких стояв Тома Аквінський намагалися пов'язати античну спадщину Аристотеля 3 середньовічною дійсністю католицької церкви. Тома Аквінський спромігся пов'язати віру і розум в одну всеохопну систему знань, у якій чіткого розмежування світської і духовної сфери не відбувалося. У його концепті суспільство уявлялося як сукупність відносин панування-підкорення. Перевагу Тома Аквінський надає монархії і зазначає, що вона має бути обмеженою, але, на жаль, не вказує в який саме інституційний спосіб відбувалося обмеження влади короля. Про демократію і ідею народного суверенітету Томою сказано небагато, але він допускав існування демократії, тобто встановлення закону народом, у випадку відсутності законодавця «висвяченого Богом $213 »$.

Натомість тлумачі Аристотеля в аверроїстській 214 традиції (Дунс Скот, Вільям Оккам, Марсилій Падуанський та інші), розглядали крізь призму філософії Аристотеля незалежність та самодостатність двох мечів (за концепцією папи Геласія I). Сфери віри і розуму були розрізненими, чітко визначалися функціональні обов'язки держави як світського початку, i церкви як духовного. Це стимулювало і інший погляд на демократію й народний суверенітет.

Найбільшим загостренням суперечки між духовною і світською владою стали конфлікти між королями Франції й правителями Німеччини 3 римськими папами. Перш за все, слід згадати полеміку Боніфація VIII 3 Філіпом IV Вродливим з приводу суверенітету влади. Надалі ця полеміка постала знову, коли папська курія почала чинити вплив у непростій ситуації королівських виборів у 30-х рр. XIV ст. У цій суперечці прихильники обох сторін за допомогою аристотелевого вчення і Святого Письма намагалися обгрунтувати верховенство влади папи, 3 боку прихильників «папського

213 Н. Палиенко. Суверенитет: Историческое развитие теории суверенитета и ее правовое значение. - Ярославль: Тип. Губ. правл., 1903. - С. 69.

214 Аверроїзм - від імені арабського філософа Ібн-Рушда, що транскрибувалося латиною як «Аверроес». 
імперіалізму» (Гілезій Римський «Про владу церкви» 1301 р.), та короля, з боку тих, хто віддавав перевагу імператору та розмежовував духовну і світську сфери (Йоанн Паризький («Про владу короля і папи»), Марсилій Падуанський («Захисник миру»)). Саме в працях прихильників другого шляху постають ідеї народного суверенітету і тих принципів, які заклали підвалини розвитку політичної філософії наступних епох - Відродження та Нового часу.

Так, наприклад, публіцист-домініканець Йоанн Паризький стверджував, що держава виникла в природний спосіб, і періоду заснування держави передувало винайдення приватної власності.

Бог наділив усіх людей спільною землею, згодом люди за допомогою розвитку праці розподілили ії на приватну власність, а правителі постають, як запобіжник виникнення розбрату між власниками цієї землі. Власність підданих державця підпадає під його юрисдикцію і без передання ними своїх прав на приватну власність. Саме тому правителі обираються 3 народної згоди. У випадку, якщо відносини між підданими і правителем втрачають довіру через те, що правитель дбає не про загальні інтереси, а про свої власні, народ може скинути такого правителя як негідного своєї служби «спільному благу» 215 . Тобто Йоанн Паризький наголошував на понятті права індивіда на приватну власність, яку він має ще до встановлення будь-якої світської чи духовної влади.

Його думки продовжив i поглибив Марсилій Падуанський, сформувавши контекстуальну концепцію політичної спільноти аристотелівського взірця.

Марсилій пише: законодавець, або перше й по-справжньому ефективне джерело закону, - це народ, або всі громадяни, або переважна частина їх, який наказує або ухвалює згідно зі своїм вибором чи волею на загальних зборах і в усталених виразах, що певні громадянські дії людей бажані або їх слід уникати під загрозою штрафу чи земного покарання $216 »$. Причиною дії станів $є$ законодавець, legislator humanus, який теоретично визначає та підтримує їх, навіть якщо передає урядові власні владні повноваження. Народ необмежений носій державної влади. «У цьому вислові, - як зазначає німецький дослідник Гайнц Рауш, - Марсилій визнає себе причетним до ідеї народного суверенітету - вчення, яке постало з часів боротьби за інвеституру; завдяки йому воно дістало найвідоміше формулювання (хоча саме поняття

215 Міллер Д. Енщиклопедія політичної думки. - Київ: «Дух і літера», 2000 - С. 153.

216 Себайн Джордж Г., Торсон Томас Л. Історія політичної думки. - К., 1997. - С. 237. 
як таке ще не оформилося)» 217. Марсилій вирішив показати, що папи і духовенство мають бути підвладні не тільки у світських справах, але й в духовній сфері усьому народові і світському володареві, який діє в інтересах цього народу. Одна з тез політичної теорії Марсилія проголошувала єдиним законним джерелом будь-яких політичних перетворень та владних повноважень тільки народ. Народові відводилася місія розробляти закони або власноруч, або через обраних ним представників, і саме народ має обирати «належний уряд, а за необхідності і розпускати його»218. Отже, Марсилій Падуанський проголошує ідею народного суверенітету та початки теорії представництва, адже тільки народ може обирати тих, хто володарюватиме над ним. Управлінці мають бути відповідальним перед народом і діяти відповідно до його інтересів.

Також до розвитку ідеї народного суверенітету долучився й англієць Вільям Оккам, хоча його доктрина дещо поступається розвитку народовладдя в політичній теорії М. Падуанського. Оккам стверджував, що джерелом будь-якого верховенства $є$ народ, саме члени спільноти мають природну владу створювати закони і призначати правителів. Але через недосконалість світської сфери мирське верховенство має бути законним навіть у тому разі, якщо воно є тиранією. У політичній сфері він по суті ігнорував владу народу, який від початку має дати свою згоду суверену, стверджуючи, що одного разу призначений правитель перебирає на себе усю владу до тих пір, поки його правління залишається корисним і сприятливим для загального добробуту 219 . Натомість Вільям Оккам більше доклав зусиль до розвитку ідей народного суверенітету та демократизму в тогочасній римо-католицькій церкві. Він $є$ одним 3 авторів, так званої «соборної теорії». Оккам порушує проблему папського абсолютизму та догмату про непогрішимість папи римського. На його думку, генеральний собор, тобто збори де б були представлені духовенство і миряни, має стати взірцем в управлінні римо-католицької церкви, а отже, саме таке управління мало здійснюватися на демократичних ідеях представництва та суверенності усіх. Вільям Оккам трансформував норму римського права «те, що стосується усіх, має примайтися усіма» - в норму канонічного права, адже тільки в такий спосіб можна було б зупинити початок розколу церкви, сучасником якого був Оккам.

217 Класики політичної думки від Платона до Макса Вебера: Пер. з нім. - Київ: Тандем, 2002. - C. 127.

218 Міллер Д. Енциклопедія політичної думки. - Київ: «Дух і літера», 2000 - С. 232.

219 Там само. С. 264. 
Великий розкол, який тривав в католицькій церкві протягом 1378-1417 років відзначився протиборством двох течій - консиліаристської, яка відстоювала ідею пріоритету рішень собору над рішеннями папи римського та абсолютистської, що наполягала на верховенстві та абсолютності влади папи римського відносно духовної сфери.

Цікавою для розвитку ідеї народного суверенітету в епоху Середньовіччя є перша лінія, адже фактично вона породила вчення про конституційне обмеження духовної і світської влади папи римського собором. Ідеї консиліаризму зародилися ще в Ранньому Середньовіччі, але свого розвитку i вивершення набули в період Високого i Пізнього Середньовіччя. Так, цікавим для нас $є$ те, що чотири Латеранські собори, які проводилися відповідно 1123 р., 1139 р., 1179 р., 1215 р., продемонстрували, що собор має владу скасовувати рішення навіть самого папи римського. Останній Латеранський собор 1215 р. за папи Інокентія III, в свою чергу, забезпечив демократичне обрання пасторів та доступ до освіти для бідних студентів 220.

Надалі відображення цих ідей бачимо і в ідеях Йоанна Паризького (визначав умови, за яких можна було б усунути папу римського та відстоював право церковного собору як верховного органу влади, якщо він складається 3 усіх членів церкви), Марсилія Падуанського (вибори місцевого духовенства та єпископів народом, засудження олігархічної тиранії папства), Вільяма Оккама (ідея про Генеральний собор як про модель урядування в римо-католицькій церкві, розробка інституційних обмежень сваволі папства).

Вагомою постаттю в консиліаристському русі був Микола Кузанський. Саме в його апеляціях до папства акцентується увага на тезі про необхідність існування собору як органу, який має в дискурсивний спосіб вирішувати вектор розвитку, догматику й місце церкви. Його демократизм щодо церковного життя римо-католицького християнства пронизаний ідеєю народного суверенітету, ба навіть початками теорії суспільної угоди.

У творі «De concordatia catholica», який М. Кузанський представив на Базельському соборі 1431 р., він зазначає: Таким чином, оскільки за природою всі люди вільні, будь-яка влада, що перешкоджає підвладним чинити зло, обмежуючи їхню свободу колом добрих вчинків через страх покарання, йде лише від гармонії й від згоди підвладних, незалежно від

220 Единбурзъкий погляд на історію демократії від давніх часів до майбутніх можливостей / за ред. Б. Айзехена та С. Стоквела. - Харків: Фоліо, 2017. - С. 198. 
того, закріплена влада писаним законом чи живим законом, яким є правитель. Бо якщо за природою люди однаково сильні чи однаково вільні, то справжня й усталена влада одного над іншим, коли правитель має таку саму природну владу, могла бути встановлена лише завдяки вибору й за згодою інших, власне як закон запроваджується через згоду»221. Звідси можна зробити висновок, що Кузанський вважає, що королем править певний договір, який пов'язує його з народом, і тільки слідування йому робить цю особу королем. Ця ідея перегукується 3 тезою англійського правника Бректона про те, що саме закон уможливлює існування короля.

Хоча консиліаризм зазнав поразки на межі XV-XVI століть, його ідеї стали наріжним каменем, на якому вибухне Реформація 3 іï ідеями демократизму та поділу церковної влади між усіма членами християнської спільноти ${ }^{222}$.

Отже, ідея народного суверенітету в епоху середньовіччя формувалася у суперечливих умовах. 3 одного боку - через перехід феодалізму до стадії абсолютизму в державному вимірі, а 3 другого шляхом антиномічного дискурсу державно-церковних відносин, у яких дві сторони намагалися легітимізувати власні інтенції та посягання на суверенітет - і державний, і церковний.

\section{ЛITEPATУРА}

1. Единбурзъкий погляд на історію демократї від давніх часів до майбутніх можливостей / за ред. Б. Айзехена та С. Стоквела. - Харків: Фоліо, 2017. - 639 с.

2. Класики політичної думки від Платона до Макса Вебера: Пер. 3 нім. - Київ: Тандем, 2002. - 584 с.

3. Міллер Д. Енщиклопедія політичної думки. - Київ: «Дух і літера», 2000 - 472 c.

4. Палиенко Н. Суверенитет: Историческое развитие теории суверенитета и ее правовое значение. - Ярославль: Тип. Губ. правл., 1903. - 591 с.

5. Рассел Бертран. Історія західної філософіï. - К., 1995. - 759 с.

6. Себайн Джордж Г., Торсон Томас Л. Історія політичної думки. - К., 1997. 838 c.

7. Hattersley A. F. A Short History of Democracy. Cambridge: Cambridge University Press, 1930.

8. Hittinger R. Reasons for a Civil Society. T. Fuller and J. Hittenger (eds). Washington, DC: Catholic University of America Press, 2001.

BA Vladyslav Sasin (Kyiv, Ukraine)

221 Себайн Джордж Г., Торсон Томас Л. Історія політичної думки. - К., 1997. - С. 237. 222 Міллер Д. Енциклопедія політичної уумки. - Київ: «Дух і літера», 2000 - С. 185. 


\section{AGES: STATE AND CHURCH VIEWS}

The article deals with the political and historical development of popular sovereignty in the Middle Ages. The reasons of revival of interest were analyzed according to the idea of popular sovereignty. Also were analyzed the characters of feudalism relations between suzerain and vassal, reception of Roman law as well as the works of Aristotle, customary law of German tribes have been used in the understanding of idea of popular sovereignty. A lot of works of medieval lawyers and philosophers (John of Salisbury, Henry de Bracton, Marsilius of Padua, William of Ockham, John of Paris, Thomas Aquinas) were analyzed in the article.

Keywords: Democracy, Popular Sovereignty, Middle Ages, Two-Swords Theory, Conciliarism, Roman law.

бакалавр Владислав Сасин (Киев, Украина)

\section{РАЗВИТИЕ ИДЕИ НАРОДНОГО СУВЕРЕНИТЕТА В СРЕДНИЕ ВЕКА:} ГОСУДАРСТВЕННОЕ И ЦЕРКОВНОЕ ИЗМЕРЕНИЯ

Статья посвящена историко-политологическому анализу развития категории «народный суверенитет» в эпоху европейского средневековья. Проанализировано возрождение интереса к идее народного суверенитета. Указано на развитие идеи народного суверенитета через призму государственной и церковной жизни. Определены места феодальных отношений (сюзерен-вассал), рецепции римского права и аристотелевского теоретического наследства, обычного права варварских племен в процессе формирования идеи народного суверенитета. Также проведен комплексный анализ работ известных средневековых юристов (Джон Солсбери, Генри Бректон) и философов (Фомы Аквинского, Марсилия Падуанского, Иоанна Парижского, Вильяма Оккама, Гилезия Римского и других) и характер описания ими народовластия. Исследованы различные социально-политические феномены в жизни европейских средневековых городов, государств и церкви, повлиявшие на становление идеи народного суверенитета в эпоху средневековья. Сделан общий вывод о влиянии средневековых подходов понимания народного суверенитета на формирование раннемодерной теории суверенитета и демократии.

Ключевые слова: демократия, народный суверенитет, эпоха Средневековья, «теория двух мечей», консилиаризм, римское право.

бакалавр Владислав Сасін (Київ, Україна)

РОЗВИТОК ІДЕЇ НАРОДНОГО СУВЕРЕНІТЕТУ ЗА ДОБИ СЕРЕДНЬОВІЧЧЯ: ДЕРЖАВНИЙ І ЦЕРКОВНИЙ ВИМІРИ

У статті наводиться історико-політологічний аналіз розвитку категорії «народний суверенітет» в епоху європейського середньовіччя. Проаналізовано причини відродження інтересу політиків та юристів до ідеї народного суверенітету. Вказано на розвиток ідеї народного суверенітету крізь призму державного і церковного життя й основних віх державно-церковних відносин в епоху 
середньовіччя. Визначено місце феодальних відносин (сюзерен-васал), рецепції римського права та аристотелевої теоретико-методологічної спадщини, звичаєвого права варварських племен у формуванні ідеї народного суверенітету. Також проведено аналіз творчого доробку правників (Джона Солсбері, Генрі Бректона) і філософів (Томи Аквінського, Марсилія Падуанського, Йоанна Паризького, Вільяма Оккама, Гілезія Римського та інших), охарактеризовано місце народовладдя в їхніх творах. Досліджено соціально-політичні феномени життя середньовічних європейських міста, держави й церкви, що спричинили вплив на дефініцію ідеї народного суверенітету в означену епоху. Зроблено загальний висновок про вплив середньовічних політичних підходів щодо народного суверенітету на формування новочасного i ранньомодерного розуміння суверенітету й демократії.

Ключові слова: демократія, народний суверенітет, епоха середньовіччя, «теорія двох мечів», консиліаризм, римське право.

* Сасін Владислав Олександрович - бакалавр політології філософського факультету, бакалавр юриспруденції юридичного факультету Київського національного університету імені Тараса Шевченка. E-mail: vladyslav.sasin@gmail.com. 